\title{
ALUZJE DO KSIĘGI SOFONIASZA W NOWYM TESTAMENCIE?
}

Nikt z badaczy Pisma Świętego nie zaprzecza tezie, że autorzy Nowego Testamentu wykorzystywali teksty ze Starego Testamentu. Wspólnota popaschalna, która wyłoniła się ze wspólnoty przedpaschalnej i była na początku tą samą wspólnotą (relacja kontynuacji), chociaż nie taką samą, bo przemienioną przez Zmartwychwstałego (relacja dyskontynuacji), od samego początku przekazywała wiernie tradycję o Jezusie Chrystusie, dokonując jednocześnie jej aktualizacji. ${ }^{1}$ Spowodowana ona była koniecznością przystosowania lingwistycznego (przełożenie głoszonych treści na język grecki); przystosowania społecznego (konieczność przejścia od charakteru wiejskiego Palestyny do świata wielkich aglomeracji miejskich basenu Morza Śródziemnego, które stawały się adresatami głoszenia kerygmatu chrześcijańskiego); przystosowania kulturowego (różne obyczaje panujące w Palestynie i w centrach helleńskich) i w końcu przystosowania kościelnego (aktualizacji nauczania Jezusa skierowanego do sobie współczesnych mieszkańców Palestyny do konkretnych warunków życia wspólnot kościelnych basenu Morza Śródziemnego). Ta sama wspólnota w przekazie tradycji odwoływała się do Starego Testamentu, ponieważ patrzyła na Jezusa Chrystusa jako na wypełnienie się Starego Testamentu. Na odwoływanie się do Starego Testamentu można spojrzeć w kontekście ówczesnej kultury pamięci i związanej z nią oralności dzieł, dzięki czemu zarówno autorzy, jak i słuchacze mieli ułatwione zadanie w odczytywaniu wpływu jednych tekstów na drugie i właściwą ich interpretację. Sam tytuł

1 Na temat kształtowania się tradycji chrześcijańskiej zob. R.A. M o n a s t e$\mathrm{r}$ i o, Introduzione ai vangeli sinottici, w: R.A. M o n a s t e r i o, A.R. C a r m o n a, Vangeli sinottici e Atti degli Apostoli, Brescia 1995, s. 21-41. 
artykułu sugeruje już, że w jakiejś mierze dotkniemy w nim problemu intertekstualności, która zajmuje się badaniem relacji między tekstami (w naszym przypadku między tekstami chronologicznie późniejszymi, tj. tymi z Nowego Testamentu, a wcześniejszymi, tj. tymi ze Starego Testamentu). ${ }^{2}$

W badaniach nad intertekstualnością podkreśla się, że dzieło literackie, a takimi są wszystkie księgi Biblii, może być najlepiej zrozumiane wtedy, gdy jest analizowane jego zapożyczenie z wcześniejszego dzieła literackiego. Zagadnienie intertekstulaności dotyczy zarówno całości danego dzieła, jak i jego poszczególnych fragmentów. W studiach o intertekstualności mówi się często o paralelach tekstualnych. Badania intertekstualne chcą zrozumieć, jak autorzy Nowego Testamentu rozumieli Stary Testament, w jaki sposób adaptowali go do własnego dzieła. Już samo wykorzystywanie tekstów ze Starego Testamentu przez autorów Nowego Testamentu pokazuje, że w punktu widzenia literackiego, ale także teologicznego, traktują oni Stary Testament jak źródło. W niniejszym artykule zajmiemy się użyciem Księgi Sofoniasza w Nowym Testamencie w kluczu aluzji, ponieważ - jak powszechnie zauważają badacze - ta księga nie jest ani razu cytowana w Nowym Testamencie. Zanim przeanalizujemy konkretne teksty z Nowego Testamentu, w których badacze dopatrują się bardziej lub mniej bezpośredniej obecności tekstów z Księgi Sofoniasza, zajmiemy się problemem obecności tekstów z tej księgi w Nowym Testamencie od strony metodologicznej.

2 Zob. R. N y c z, Intertekstualność i jej zakresy: teksty, gatunki, światy, Pamiętnik Literacki: czasopismo kwartalne poświęcone historii i krytyce literatury polskiej 81(1990) nr 2, s. 95-116; P. B o b o w s k a - N a s t a r z e w s k a, O intertekstualności na przykładzie własnego tłumaczenia książki Paula Ricoera, ,, Refleksja dokonana. Autobiografia intelektualna”, Rocznik Przekładoznawczy. Studia nad teorią, praktyką i dydaktyką przekładu 5/2009, s. 53-68 (autorka w pierwszej części artykułu omawia rozumienie intertekstualności przez H. Markiewicza, R. Nycza, E. Kasperskiego, G. Genette, W. Borowego). 


\section{Księga Sofoniasza w Nowym Testamencie jako problem metodologiczny}

Jak już zauważyliśmy, Nowy Testament ani razu nie cytuje Księgi Sofoniasza. Od samego początku zatem badacz ma utrudnione zadanie, ponieważ nie spotkamy w nim formuł, chociażby takich na wzór Mateuszowych formuł wypełnienie („A stało się to wszystko, aby się wypełniło słowo Pańskie powiedziane przez Proroka": Mt 1,22), które wprowadzałyby teksty z Księgi Sofoniasza. Edytorzy wydań krytycznych Nowego Testamentu umieszczają tę księgę w indeksie aluzji i słownych paraleli. Tutaj pojawia się problem zdefiniowania aluzji. Wielkie zasługi na tym polu położył Konrad Górski, który w swoim opracowaniu napisał: „Przez aluzję literacką będziemy więc rozumieć aluzyjne nawiązanie do tekstu innego dzieła literackiego, dzięki czemu dany utwór posługuje się w większym lub mniejszym stopniu zawartością drugiego utworu jako sposobem wyrażenia własnej treści”. ${ }^{3}$ Za Konradem Górskim należy przyjąć także, że aluzja to „środek wyrazu” czy „rodzaj środka artystycznego”, co zakłada świadome i celowe użycie. ${ }^{4}$ Aluzja literacka - jak zauważa T. Kostkiewiczowa - może przybrać postać nawiązania do tytułu innego dzieła, ale także występuje w postaci nawiązania do sytuacji przedstawionej w innym dziele, do całokształtu tego utworu, do elementów świata w nim przedstawionych czy też jest nawiązaniem stylistyczno-frazeologicznym, weryfikacyjnym a nawet rymowym. ${ }^{5}$ Analizując każdą aluzję, jak i cytację, należy wziąć pod uwagę dwa pokrywające się konteksty aluzji czy cytacji. „Każda aluzja powinna być egzaminowana jako element zarówno tekstu źródłowego, jak i tekstu w którym jest ta aluzja. Późniejszy autor mógł użyć aluzyjną frazę, aby odesłać czytelnika do całego passusu, z którego ta fraza

3 K. Gó r s k i, Aluzja literacka (Istota zjawiska i jego typologia), w: t e n ż e, $Z$ historii i teorii literatury. Seria druga, Warszawa 1964, s. 7-8.

4 Por. tamże.

5 T. Ko s t k i e w i c z o w a, Aluzja literacka, w: J. S ła w iń s k i (red.), Słownik Terminów Literackich, Wrocław-Warszawa-Kraków-Gdańsk-Łódź 1988, s. 26. 
jest wzięta. Aluzja może być rozumiana jako przywołanie tematu czy kompleksu idei w oryginalnym passusie tekstu". ${ }^{6}$ Przy analizie aluzji należy zatem odpowiedzieć na pytanie o jej rolę w nowym kontekście.

J. Paulien, zajmując się aluzjami do Starego Testamentu w Apokalipsie, zaproponował kryteria, które dość precyzyjnie określają, czym jest cytat, a czym aluzja. $Z$ cytatem mamy do czynienia wtedy, kiedy następuje zbieżność i szyk użytej terminologii, natomiast $\mathrm{z}$ aluzją, jeśli notuje się ewentualną zbieżność słowną lub zbieżność kontekstu. Wśród aluzji badacz wyróżnia - w zależności od stopnia zbieżności z tekstem wyjściowym - aluzje pewne, prawdopodobne, możliwe oraz echa (aluzje o najniższym stopniu prawdopodobieństwa). ${ }^{7}$ G.K. Beale, analizując użycie Starego Testamentu w Apokalipsie wyróżnia trzy rodzaje aluzji: aluzje oczywiste, które charakteryzują się identyczną terminologią i wspólnym znaczeniem, wykluczającym inne pochodzenie; aluzje prawdopodobne, w których nie spotyka się tego samego słownictwa, natomiast podobieństwo dotyczy bardziej idei lub wyrażeń typowych dla Starego Testamentu; aluzje możliwe, w których język jest zbliżony do przypuszczalnego źródła. ${ }^{8}$

Gary T. Manning Jr, analizując użycie Księgi Ezechiela w Nowym Testamencie i w literaturze okresu Drugiej Świątyni, wypracował metodę w analizie aluzji, którą można z powodzeniem zastosować w rozwiązaniu kwestii aluzji do Księgi Sofoniasza w Nowym Testamencie. Jego metoda obejmuje trzy kroki: wyselekcjonowanie tekstów

6 G.T. M a n n ing Jr, Echoes of a Prophet. The Use of Ezekiel in the Gospel of John and in Literature of the Second Temple Period, JSNT Supplement Series 270, London-New York 2004, s. 5. Cały pierwszy rodział tej monografii, zatytułowany Introduction and Method (s. 1-21) jest znakomitym wprowadzeniem do analizy użycia tekstów Starego Testamentu w Nowym Testamencie.

7 J. P a u 1 i e n, Criteria and Assessment of Allusions to the Old Testament in the Book of Revelations, w: S. M o y i s e (red.), Studies in the Book of Revelation, Edinburgh 2001, s. 113-129. Na temat rodzajów aluzji zob. także M. K a r c z e ws k i, Reinterpretacja Księgi Rodzaju w Apokalipsie św. Jana, Biblioteka Wydziału Teologii Uniwersytetu Warmińsko-Mazurskiego w Olsztynie nr 55, Olsztyn 2010, s. $71-76$.

8 G.K. B e a le, The Book of Revelation, NICTC, Grand Rapids 1999, s. 77-78. 
z możliwymi aluzjami; wykazanie siły aluzji; określenie użycie tej aluzji. ${ }^{9}$ Zasadniczą kwestią do rozwiązania jest sprawa kryteriów, które należy wziąć pod uwagę przy ustaleniu wagi danej aluzji. Wydaje się, że głównymi kryteriami mogą być: ${ }^{10}$ liczba podobnych słów lub fraz (im więcej takich samych czy podobnych słów i fraz, tym aluzja jest pewniejsza; bardziej sugestywna jest jednak liczba fraz niż pojedynczych słów); podobny sposób użycia słów lub fraz (powinna być podobna rola narracyjna czy cel teologiczny; zdanie może używać podobnych słów, ale jeśli słowa mają zupełnie inną funkcję w dwóch passusach, to trudno mówić tutaj o aluzji); wykluczenie innych możliwych źródeł (w tym celu należy dokonać porównania z innymi paralelnymi passusami). Te trzy kryteria, wskazują jedynie na słowny paralelizm między dwoma passusami tekstu, dlatego wagę aluzji może wzmocnić jeszcze: paralelizm strukturalny; powtórzenie aluzji w podobnym passusie; oddźwięk lub zgodność oryginalnego kontekstu i nowego kontekstu aluzji.

Określenie kryteriów, które decydowałyby o tym, czy w wykorzystaniu tekstu ze Starego Testamentu w Nowym mamy do czynienia z aluzją, pozostaje sprawą otwartą. Dla potrzeb tego artykułu przyjęliśmy następującą metodykę: po pierwsze, wskażemy teksty z Nowego Testamentu, w których można dostrzec aluzje do Księgi Sofoniasza; po drugie, przeanalizujemy każdą z tych aluzji, odpowiadając na pytanie o wagę, rolę i cel każdej z nich w nowym kontekście.

\section{Wykaz możliwych miejsc z aluzjami do Księgi Sofoniasza w Nowym Testamencie}

Aby wykazać aluzje, należy założyć, że autor Nowego Testamentu musiał mieć możliwość dotarcia do tekstu Księgi Sofoniasza albo w ogóle znał tę księgę. Trudno jest wyobrazić sobie sytuację, aby autorzy Nowego Testamentu nie znali tej księgi, jak i zresztą całego Starego Testamentu, skoro w kształtowaniu i przekazywaniu tradycji

9 G.T. Ma n n ing Jr, Echoes of a Prophet, s. 7-19.

10 Kryteria za: tamże, s. 9-14. 
chrześcijańskiej - jak to podkreśla większość badaczy - odwoływano się do Starego Testamentu. Żydzi podkreślali, że Tora ma $70 \mathrm{oblicz}$ i to, czego nie ma w Torze, tego nie ma w świecie. Jedną z metod egzegetycznych była egzegeza draszowa (od hebrajskiego słowa drasz „poszukiwać”, ,indagować”), której założeniem fundamentalnym była jedność Pisma i konieczność wyjaśnienia każdego jego tekstu przez odwołanie się do innych tekstów Pisma. ${ }^{11}$ Autorzy Nowego Testamentu w wielu miejscach korzystali z takiego typu egzegezy. Jedną z siedmiu Zasad Objaśniania Tory ułożonych przez Hillela była Gzeira szawa, która mówiła, że ,podobne słowa występujące w różnych kontekstach są pomocne w objaśnieniu obu kontekstów". ${ }^{12}$ Podstawowym kluczem zatem do wyselekcjonowania tekstów z Nowego Testamentu, w których są możliwe aluzje do Księgi Sofoniasza, są słowa i frazy, występujące w tej księdze i konkretnych tekstach z Nowego Testamentu.

Śledząc najbardziej popularne wydania krytyczne greckiego Nowego Testamentu, tj. Nestle-Alland oraz The Greek New Testament, konsultując ich propozycję z komentarzami do Księgi Sofoniasza oraz odpowiednich ksiąg nowotestamentowych, sporządziliśmy tabelę, która pokazuje możliwe aluzje w tekstach Nowego Testamentu do konkretnych tekstów z Księgi Sofoniasza.

\begin{tabular}{|c|c|c|c|}
\hline & N-A & GNT & Komentarze \\
\hline So 1,7 & Ap 8,1 & & \\
\hline So 1,3 & & Mt 13,41 & Mt 13,41 \\
\hline So 1,14 & Rz 2,5; Ap 6,17 & & \\
\hline So 1,18 & Hbr 10,27 & & \\
\hline So 3,8 & Ap 16,1 & Ap 16,1 & Ap 16,1 \\
\hline
\end{tabular}

${ }^{11}$ Na temat tej metody zob. F. M a n n s, Le Midrash. Approche et commentaire de l'Escriture, Jérusalem 1990; D. M u ñ o z L e ó n, Derás. Los caminos y sentidos de la Palabra Divina en la Escritura, Madrid 1987; M. R o s i k, I. R a p o p o r t, Wprowadzenie do literatury i egzegezy żydowskiej okresu biblijnego i rabinicznego, Wrocław 2009, s. 172-177.

12 Na temat zasad Hillela zob. tamże, s. 183-184. 


\begin{tabular}{|c|c|c|c|}
\hline So 3,10 & Dz 8,27 & & \\
\hline So 3,13 & Ap 14,5 & Ap 14,5 & Ap 14,5 \\
\hline So 3,14 & J 12,15 & & \\
\hline So 3,15 & $\begin{array}{c}\text { Mt 27,42; Mk 15,32; } \\
\text { J 1,49; 12,13 }\end{array}$ & J 1,49 & \\
\hline
\end{tabular}

Z tego zestawienia wynika, że niewiele tekstów z Księgi Sofoniasza znajduje swoje paralele w Nowym Testamencie. Trzeba jednak pamiętać, że jest to krótka księga. Do szczegółowej analizy wybraliśmy jedynie te aluzje, które są wymienione przynajmniej przez dwóch edytorów bądź jednego edytora i komentatorów. Tak więc przedmiotem naszych badań stały się teksty z So 1,3; 3,8; 3,13 i 3,15, z nadzieją, że wyprowadzone wnioski mogą stać się reprezentatywne dla odpowiedzi na pytanie o wykorzystanie tej księgi w Nowym Testamencie.

\section{Analiza poszczególnych tekstów}

Nasza analiza tekstów z Księgi Sofoniasza w Nowym Testamencie ma odpowiedzieć przede wszystkim na pytania o wagę tej aluzji i jej znaczenie w nowym kontekście. Już na samym początku dotykamy problemu, z jakiego tekstu źródłowego Starego Testamentu mogli korzystać autorzy Nowego. Nie ulega wątpliwości, że Biblią pierwszych chrześcijan była Biblia Grecka, czyli Septuaginta, dotarła ona jednak do naszych czasów, podobnie jak i inne teksty biblijne, jedynie w odpisach. Trzeba jednak pamiętać, że w Nowym Testamencie znajdują się także teksty zawierające cytacje czy aluzje do tekstu hebrajskiego. W tym przypadku pozostaje pytanie: Do jakiego tekstu hebrajskiego odwołują się te teksty: przedmasoreckiego, z którego wyłonił się tekst masorecki; innej matrycy tekstu (niem. Vorlage), z której prawdopodobnie korzystali tłumacze Septuaginty; do tekstu, który był w użyciu w Qumran; a być może do jeszcze innego typu tekstu hebrajskiego? ${ }^{13}$ Dlatego w naszej analizie punktem wyjścia

13 Na te trudności w docieraniu do tekstów zbliżonych do oryginału zwróciła uwagę na przykładzie Księgi Przysłów B. S tr z ałkow s k a, Księga Przysłów 
będzie tekst hebrajski (TM) i tekst grecki (LXX) So z wydań krytycznych Biblii Hebrajskiej i LXX.

So 1,3

TM:

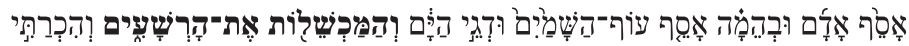

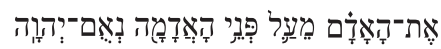

LXX:

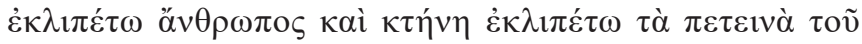

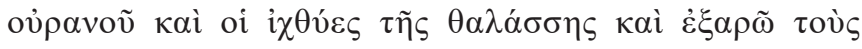

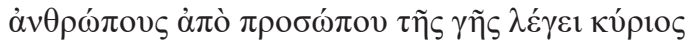

„Usunę ludzi i bydło, usunę ptactwo podniebne i ryby morskie, i zgorszenie wraz z bezbożnymi; i wytępię człowieka z powierzchni ziemi - wyrocznia Pana".

Badacze dość jednoznacznie dostrzegają aluzję do tego tekstu w Mt 13,41:

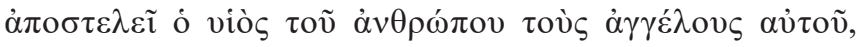

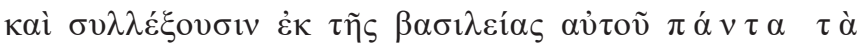

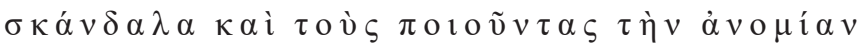

„Syn Człowieczy wyśle aniołów swoich: ci zbiorą z Jego królestwawszystkie zgorszenia oraztych, którzy dopuszczają się nieprawości”.

1-9 w Septuagincie. Analiza ,dodatków” i „,braków” w zestawieniu z Tekstem Masoreckim w świetle starożytnych świadectw tekstualnych, Rozprawy i Studia Biblijne 48, Warszawa 2017, s. 14-83. 
So 1,3 należy do pierwszej części księgi (Sąd Boży nad Judą i nad światem). Sąd Boży nad Judą (1,4-16) jest umieszczony w kontekście dnia JHWH - dnia gniewu (Dies Irae), na który autor patrzy z perspektywy kosmicznej i uniwersalistycznej, dopiero potem następuje wyrocznia - osąd przeciw Judzie. ${ }^{14}$ Przesłanie jest jasne: ten dzień się przybliża, zatem jest jeszcze czas na nawrócenie, jeśli zaś ono nie nastąpi, to będzie za późno, kiedy już dzień YHWH nastanie. W całej księdze mamy podobny schemat: osąd uniwersalny (1,2-3) i osąd nad Judą (1,4-2,3); osąd nad poganami (2,4-15) i osąd nad Jerozolimą (3,1-8). Na końcu jednak mamy wyrocznię ocalenia (3,9-20). ${ }^{15}$

Cała fraza So 1,2-3, wyliczając różne zwierzęta i człowieka, przypomina rozdział o stworzeniu $\mathrm{z} \operatorname{Rdz} 1,1-2,4 \mathrm{a}$ (nawet jeśli jest to późniejsze od Sofoniasza) czy opis potopu z Rdz 6. Znajdujemy się w swojego rodzaju antykreacji (podobnie mamy w potopie), jakby nowym potopie, przez który ma zostać unicestwiony każdy rodzaj życia. W tekście hebrajskim Księgi Sofoniasza wśród tego, co jest przeznaczone na zgubę, niektóre manuskrypty mają ,zgorszenia” (w hamakeszelot) i ,złych” (har ${ }^{e}$ szaim). Nie wymienia ich tekst grecki Starego Testamentu. Zestawienie ,zgorszenia” i ,złych” znajduje się tylko w tym starotestamentowym tekście. Słowo makeszlot (,,zgorszenia") jest hapax legomenon w Starym Testamencie. Zaś drugie słowo spotykamy jeszcze w Wj 9,27; Lb 16,26; Ps 1,4; 11,12; 145,20; Koh 8,14; Jr 25,31 i oznacza ono „złych”, „występnych”, „bezbożnych” (tych, którzy przeciwstawią się swoim postępowaniem Prawu). Jest ono różnie tłumaczone w LXX: jako asebēs, sklēros, hamartōlos.

14 Zob. G.A. K ing, The Day of the Lord in Zephaniah, Bibliotheca Sacra 152/1995, s. 16-32.

15 Na temat różnych propozycji struktury Księgi Sofoniasza zob. L.A. S c h ö k e l, J.L.S. D i a z, I Profeti, traduzione e commento, Roma 1996, s. 1266-1268; zob. T. B r z e g o w y, Ubodzy duchem dostapia zbawiania (Księga Sofoniasza), w: T. Brzegow y, J. Frankowski, M. Gołebi ewski (oprac.), Wielki świat starotestamentalnych proroków I. Od poczatków profetyzmu do Niewoli Babilońskiej, Wprowadzenie w Myśl i Wezwanie Ksiąg Biblijnych 4, Warszawa 2001, s. 156-157. 
Wiersz Mt 13,41 należy do perykopy, w której opisane jest wyjaśnienie przypowieści o chwaście na roli (13,36-42). Koniec czasów jest czasem żniwa, w którym zbiera się chwast i spala w ogniu (chodzi zatem o całkowite unicestwienie). Chwastem są ,zgorszenia oraz ci, którzy czynią nieprawość" (panta ta skandala kai tous poiountas tēn anomian). Słowo anomia (,nieprawość”) w Ewangeliach występuje jedynie u Mt $(7,23 ; 13,41 ; 23,28 ; 24,12)$ i zawiera dwa elementy: odmowę pełnienia woli Bożej oraz brak miłości. ${ }^{16} \mathrm{~W}$ rozumieniu Mateuszowym jest przeciwieństwem „sprawiedliwości” (dikaiosynē). W całej tradycji biblijnej „czyniącymi nieprawość” są ci, którzy przekraczają Prawo. Mateusz tłumaczy być może hebrajskie słowo har szaim na swój sposób, jako „czyniący nieprawość” (tous poiountas tès anomias). To tłumaczenie jednak semantycznie odpowiada propozycjom LXX. O sile zestawienia ,zgorszeń” i „czyniących nieprawość" świadczy fakt, że spotykamy je tylko w dwóch miejscach całej Biblii: właśnie u Sofoniasza i Mateusza. Wagę tej aluzji podkreśla również podobieństwo kontekstu: dzień $\mathrm{YHWH}$, podobnie jak dzień żniwa, jest dniem sądu. W tradycji nowotestamentalnej sąd Boga nad światem jest wzorowany na prorockim dniu YHWH ${ }^{17}$ i być może lepiej byłoby w tym miejscu mówić o aluzji ogólnej czy też-używając terminologii G.K. Beale - aluzji możliwej do tradycji prorockiej. ${ }^{18}$ Należy jednak jednocześnie zauważyć, że trudno byłoby znaleźć inne źródło dla tekstu Mateusza niż tekst Sofoniasza, dlatego wydaje się, że mamy tutaj do czynienia z aluzją oczywistą, chociaż nie da się wykluczyć innego wniosku: Mateusz, znając wymowę dnia YHWH w Starym Testamencie, mógł stworzyć własny odpowiednik czy wizję tego dnia.

16 A. P a c i or e k, Ewangelia wedtug świętego Mateusza, rozdziały 1-13, NKBNT I/1, Częstochowa 2004, s. 555.

17 Na temat „dnia Pańskiego” zob: R.H. H i e r s, Day of the Lord, w: The Anchor Bible Dictionary, t. 2, New York-London-Toronto-Sydney-Auckland 1992, s. 82-83; H.J. C a th c a r t, Day of Yahweh, w: tamże, s. 84.

18 Por. G.K. B e a l e, D.A. C a r s o n, Introduction, w: c i ż (red.), Commentary on the New Testament Use of the Old Testament, Grand Rapids 2007, s. XXV. 
Wymowa tego tekstu staje się jeszcze mocniejsza, jeżeli przyjmujemy zastosowanie w nim zasady gzeira szawa, która mówi - jak to już zauważyliśmy - że podobne słowa występujące w różnych kontekstach są pomocne w objaśnianiu obu kontekstów. Nie rozstrzygamy tutaj kwestii, czy taką regułę stosował sam historyczny Jezus czy autor Ewangelii wg św. Mateusza. W Ewangelii Mateusza dzień żniwa, który jest opisem nadejścia Syna Człowieczego, przybiera cechy dnia YHWH. Protagonistą całego dnia jest Syn Człowieczy. Zestawienie tych cech z Księgą Sofoniasza pozwala przypuszczać, że w Ewangelii Mateusza aluzja do tekstu Sofoniasza - jeśli istnieje ma wydźwięk chrystologiczny. Mamy do czynienia z reinterpretacją chrystologiczną tekstu Księgi Sofoniasza, w którym przymioty samego Boga przechodzą na Jezusa Chrystusa. Dla Mateusza teologia staję się chrystologią.

\section{So 3,8}

TM:

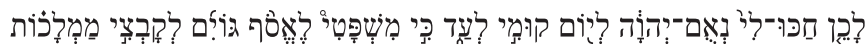

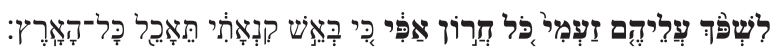

\section{LXX:}

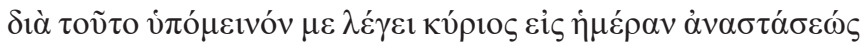

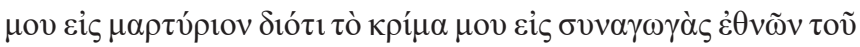

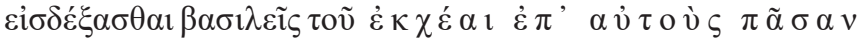

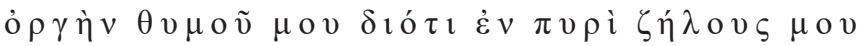
$\kappa \alpha \tau \alpha v \alpha \lambda \omega \theta \dot{\eta} \sigma \varepsilon \tau \alpha 1 \pi \tilde{\alpha} \sigma \alpha \dot{\eta} \gamma \tilde{\eta}$

„Przeto oczekujcie na Mnie - wyrocznia Pana - w dniu, gdy powstanę jako oskarżyciel, bo postanowiłem zgromadzić narody, zebrać królestwa, aby wylać na nie cały gniew oburzenia mojego, bo ogień mej żarliwości pochłonie całą ziemię". 
Ap 16,1:

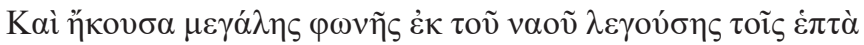

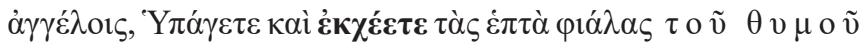
$\tau$ o v $\theta \varepsilon$ o v $\varepsilon i \varsigma \tau \dot{\eta} v \gamma \tilde{\eta} v$.

„Potem posłyszałem donośny głos ze świątyni, mówiący do siedmiu aniołów: «Idźcie, a wylejcie siedem czasz gniewu Boga na ziemię!»".

Tekst z So 3,8 znajduje się w kontekście opisu osądu nad Jerozolimą. So 3,8 podsumowuje ten osąd i jest zarazem przejściem do wyroczni o odnowieniu ludu. W przypadku Apokalipsy jesteśmy w narracji o siedmiu czaszach gniewu Boga (16,1-21). Tekst LXX wiernie oddaje tekst hebrajski. Sofoniasz mówi o wylaniu (czasownik ekchein) na narody i królestwa „całej zapalczywości gniewu mojego”

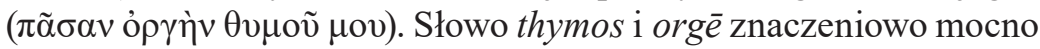
zbliżają się do siebie. Cała fraza wskazuje na pełnię gniewu Boga. W Apokalipsie mówi się także o pełni gniewu Boga (symbolika siedmiu czasz). Mamy ten sam czasownik ekchein (,wylać”). Podobieństwo obu tekstów jest ewidentne. Czy jednak jest to aluzja do So 3,8? W LXX fraza ekchein + thymos wskazuje na osąd na tymi, którzy łamią przymierze, bądź nad tymi, którzy prześladują lud Boży. ${ }^{19}$ Czasem ta formuła zostaje poszerzona o ogień, podobnie, jak to jest w So 3,8. Trudno jest jednak udowodnić tezę, że autor Apokalipsy wykorzystał w swoim dziele So 3,8 i to z jednego powodu. Formułę ekchein + thymos spotykamy w licznych tekstach Starego Testamentu (por. Ez 7,9; 9,8; 14,19; 20,8; 13,21; 21,36; 22,22; 30,15; 39,29; Jr 10,25; Lm 4,11; Ps 68,25). Według mnie lepiej jest mówić o aluzji możliwej czy nawet o echu tekstów starotestamentowych (zwłaszcza tekstów prorockich) w Ap 16,1 niż o aluzji do konkretnego tekstu ze Starego Testamentu.

19 G.K. B e a l e, S.M. M c D o n o u g h, Revelation, w: tamże, s. 1135. 


\section{So 3,13}

TM:

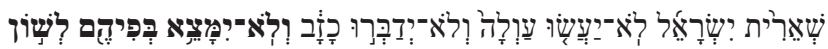

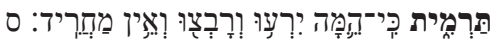

\section{LXX:}

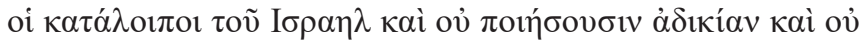

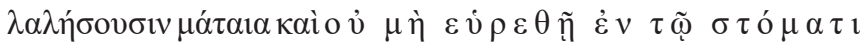

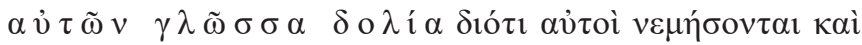

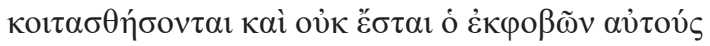

„Reszta Izraela nie będzie czynić nieprawości ani mówić kłamstwa. I nie znajdzie się w ich ustach zw o d n i c z y ję z y k, gdy paść się będą i wylegiwać, a nie będzie nikogo, kto by ich przestraszył”.

Ap 14,5:

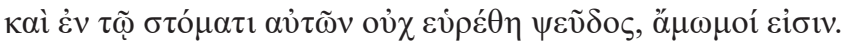
,a w ustach ich kłamstwa nie znaleziono: są nienaganni”.

Dlaczego można mówić o aluzji w tym przypadku? Ponieważ w całej Biblii znajdziemy jedynie dwa teksty, które stosują frazę: „W ustach ich nie znaleziono". Jest to właśnie So 3,13 i Ap 14,5. ${ }^{20}$

Księga Sofoniasza po wyroczniach osądu nad ziemią i Judą, poganami i Jerozolimą, przekazuje obietnicę ocalenia, związaną z Resztą Izraela. W ostatnich dniach Bóg ocali Resztę Izraela, którą prorok utożsamia z „świętą górą” i „Syjonem”. Podobne sformułowanie do analizowanego przez nas znajdziemy także w Iz 53,9, w Pieśni

${ }^{20}$ Na tę aluzję wskazuje D.E. A u n e, Revelation 6-16, WBC 52b, Nashville 1998, s. 823 . 


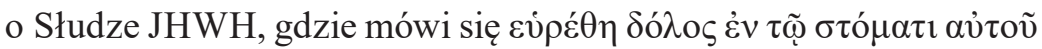
(,nie zostało znalezione kłamstwo w jego ustach”).

Ap 14,5 należy do perykopy, która opisuje orszak Baranka, który jest przeciwstawiony tym wszystkim, którzy adorują Bestię (państwo czy system, który chce zastąpić Boga ${ }^{21}$ ). Na ten orszak Baranka można patrzeć w kluczu jakiejś reszty, która nie przynależy do „mieszkańców ziemi” (144 tys.). Znajduje się ona wraz z Barankiem na górze Syjon. Są nimi chrześcijanie, którzy przynależą do Boga i Baranka. W Ap 14,4-5 zostaje doprecyzowana ich tożsamość: „Ci są, którzy z kobietami się nie splamili, bo są dziewicami, ci, którzy idą za Barankiem, dokądkolwiek idzie, ci, którzy zostali z ludzi wykupieni jako pierwocina dla Boga i dla Baranka, i w ich ustach kłamstwa nie znaleziono, są nienaganni”. Autor Apolalipsy, nawiązując do tekstu So 3,13 o Reszcie Izraela, chce pokazać, że to proroctwo spełnia się w chrześcijanach. Mamy zatem znowu do czynienia z reinterpretacją teologiczną. ${ }^{22}$

Wykorzystanie tekstu So 3,13 można rozszerzyć także na inne teksty z Nowego Testamentu, nawiązuje on do Reszty Izraela. Samo to pojęcie jest podjęte przez Sofoniasza prawdopodobnie za Amosem (por. 5,3.15; 9,8) i Iz $(6,13 ; 7,3)$, jednocześnie jednak Sofoniasz w 3,12 precyzuje charakterystykę tej grupy, nazywając ich „ubogimi ziemi”. T. Brzegowy zauważa: „Ubodzy ziemi, postawieni przez Sofoniasza w paralelizmie z tymi, którzy zachowując przykazania, to ludzie mało albo nic nie posiadający w dziedzinie materialnej, ale bogaci ufnością w Opatrzność Bożą. Oni całkowicie zdają się na Boga i tylko od niego oczekują zbawienia". ${ }^{23}$ Sofoniasz jest uważany za twórcę nurtu teologii ubóstwa, który znajdzie swoje rozwinięcie u Jeremiasza, Pieśniach o Słudze YHWH czy w Psalmach. Echo takiego spojrzenia na

21 Na temat interpretacji dwóch Bestii z Ap 13 zob. D. K o t e c k i, Duch Święty w zgromadzeniu liturgicznym $w$ świetle Apokalipsy św. Jana, Rozprawy i Studia Biblijne 26, Warszawa 2006, s. 70-81.

22 Zob. te n ż e, Kościót w świetle Apokalipsy św. Jana, Częstochowa 2008, s. $239-240$.

23 T. B r z e g o w y, Ubodzy duchem dostapia zbawienia, s. 162-163. 
ubóstwo odnaleźć można w Nowym Testamencie. „Najwyższą rangę otrzymała ta nauka - jak napisał T. Brzegowy - w ustach samego Jezusa, który konstytucję nowego Ludu Bożego rozpoczął słowami: «Błogosławieni ubodzy duchem» (Mt 5,3). Najszlachetniejszą przedstawicielką tego nurtu ubogich była «Służebnica Pańska», Maryja, która wielbiła Boga za to, że «strąca władców z tronu, a wywyższa pokornych» (Łk 1,52; por. ww. 38 i 48)". ${ }^{24}$

\section{So 3,15}

TM:

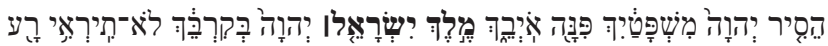

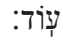

\section{LXX:}

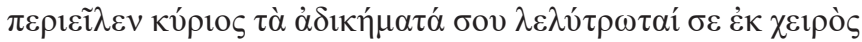

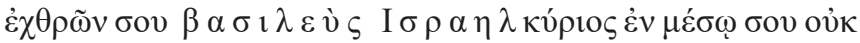

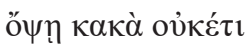

„Oddalił Pan wyroki na ciebie, usunął twego nieprzyjaciela: k ró 1 I z ra ela, Pan, jest pośród ciebie, nie będziesz już bała się złego".

Tekstem, który miałby odnosić się do So 3,15 jest tekst z J 1,49, w którym Jezus jest nazwany przez Natanaela Królem Izraela:

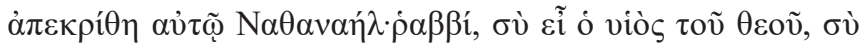

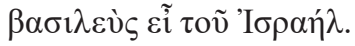

„Odpowiedział Mu Natanael: Rabbi, Ty jesteś Synem Bożym, Ty jesteś Królem Izraela".

24 Tamże, s. 164. 
W całym Starym Testamencie, kiedy używa się wyrażenia „król Izraela", w większości przypadków odnosi się on do konkretnych postaci historycznych związanych z historią narodu wybranego. Wyjątkami są dwa teksty. Przytoczony powyżej z So 3,15 oraz Iz 44,6:

TM:

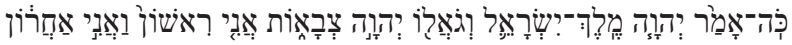

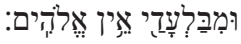

\section{LXX:}

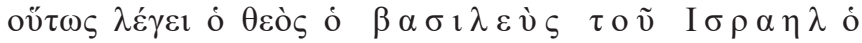

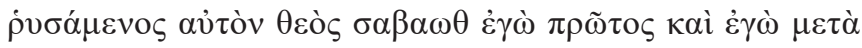

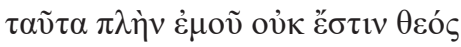

„Tak mówi Pan, K ról I z ra e la i Odkupiciel jego, Pan Zastępów: Ja jestem pierwszy i Ja ostatni; i nie ma poza Mną boga".

Tekst Iz 44,6 powinien być rozpatrywany w kontekście ekskluzywnego monoteizmu: tylko YHWH jest jedynym Bogiem. Ten tekst jest wykorzystywany w kilku miejscach przez autora Apokalipsy w odniesieniu do Jezusa zmartwychwstałego i jest przykładem stosowania przez niego teocentryzmu chrystologicznego. ${ }^{25}$ Oczywiście tekstów, które mówią o Bogu jako królu jest znacznie więcej w całym Starym Testamencie (zob. Ps 45; 47; 93; 96-99; 145). Natanael wyznaje: „Rabbi, Ty jesteś Synem Bożym, Ty jesteś Królem Izraela”. W niektórych tekstach Starego Testamentu mamy do czynienia z połączeniem idei Mesjasza, jako króla dawidowego z ideą Syna YHWH (por. 2Sm 7,14; Ps 89,27; Ps 2,6-7). Jednak tytuł „król Izraela” nie zostaje zastosowany do Mesjasza w Starym Testamencie, a jedynie do Boga. Być może zatem Jan chce nadać tytułowi „Syn Boży” głębszego

25 Na ten temat zob. D. K o te c k i, Jezus a Bóg Izraela, Scripta Theologica Thoruniensia 27, Toruń 2013, s. 57-58. 
znaczenia i cała formuła zostaje uzupełniona przez zapożyczony z Księgi Sofoniasza tytuł „Król Izraela”, aby w mesjańskim tytule „Syn Boży” zawrzeć już przekonanie o boskiej godności Jezusa. ${ }^{26}$ Można w tym miejscu mówić o reinterpretacji chrystologicznej tytułu zarezerwowanego dla Boga w Starym Testamencie. On patrzy na Jezusa jako uczestnika tej samej natury jedynego Boga Izraela. ${ }^{27}$

$$
* * *
$$

Podsumowując, użycie Księgi Sofoniasza w Nowym Testamencie na pewno nie jest ewidentne. Nie mamy tutaj cytatów bezpośrednich. Z punktu widzenia literackiego można jedynie dostrzec pewne aluzje czy echa. Jeśli przyjęlibyśmy w ogóle istnienie tych aluzji, to na pewno ich użycie wpisuje się w reinterpretację teologiczną, a zwłaszcza chrystologiczną. Pozostaje jednak sprawą otwartą, czy są to aluzje w sensie ścisłym. Wykorzystanie tekstów z Księgi Sofoniasza w Nowym Testamencie można bowiem traktować w kategoriach jakiejkolwiek wpływologii (związki i zależności literackie), o której już w 1921 r. mówił W. Borowy, wyróżniając wpływy i zależności ideowe (zbieżność myśli religijnej, filozoficznej, psychologicznej czy historycznej), wpływy i zależności techniczne (podobieństwa w budowie utworów, należących do tych samych gatunków literackich), wpływy i zależności tematyczne (zgłębianie tych samych wątków i zagadnień), świadome lub mimowolne wpływy i zależności stylistyczne, umyślne, nieumyślne lub plagiatowe wpływy o zależności frazeologiczne widoczne w zwrotach używanych przez myślicieli pod

26 Por. R.E. B row n, Giovanni. Commento al Vangelo spirituale, Assisi 1979, s. 116-117; S. M ę d a l a, Ewangelia wedtug św. Jana, rozdziały 1-12, NKB NT IV/1, Częstochowa 2008, s. 331.

27 Nie wszyscy badacze w wyznaniu Natanaela dostrzegają wyraz wiary w bóstwo Jezusa a jedynie mesjańskich oczekiwań żydowskich; zob. H. W i t c z y k, Kościót Syna Bożego. Studium eklezjologii Czwartej Ewangelii, Biblioteka „Verbum Vitae" t. 3, Kielce 2012, s. 185. 
wpływem drugiego. ${ }^{28}$ Trudno jest jednoznacznie stwierdzić, opierając się na wykorzystaniu pojedynczych słów z Księgi Sofoniasza w niektórych tekstach Nowego Testamentu, że mamy tam do czynienia $\mathrm{z}$ aluzją w sensie ścisłym. Dlatego tytuł tego artykułu, opartego na dokonanych analizach, pozostawiłbym bez zmian, $\mathrm{tj}$. ze znakiem zapytania.

ks. Dariusz KOTECKI

Słowa kluczowe: Sofoniasz, aluzja, użycie Starego Testamentu w Nowym Testamencie

Keywords: Zephaniah, allusion, the Old Testament's use in the New Testament

Allusions to the Book of Zephaniah in the New Testament? Summary

In the New Testament there are no citations from the Book of Zephaniah. There are only allusions which are understood as references to another work of literature thanks to which a given text uses the content of other literature to a greater or lesser extent as a way of expressing its own content. The author of the article analyses the following allusions: to Zep 1:3 in Mt 13:41; to Zep 3:8 in Rev 16:1; to Zep 3:13 in Rev 14:5 and to Zep 3,15 in Jn 1:49, asking about their importance and weight. He comes to the conclusion that some of them are very probable (e.g. Zep 1:3 in Mt 13:41; Zep 3:13 in Rev 14:5 or Zep 3,15 in Jn 1:49) and others should be viewed as the echo of prophetic texts (e.g. Zep 3:8 in Rev 16:1). However, in all cases we can observe the reinterpretation of the Book of Zephaniah in a new Christological (Zep 1:3 in Mt 13:41; Zep 3,15 in Jn 1:49), ecclesiological (Zep 3:13 in Rev 14:5) or theological (Zep 3:8 in Rev 16:1) context.

28 W. B o row y, O wpływach i zależnościach w literaturze, Kraków 1921, s. $7-45$. 